\title{
CONTINUOUS ORAL ADMINISTRATION OF MEGESTROLACETATE TO WOMEN
}

\author{
H. A. VAN LEUSDEN* \\ St Elisabeth's Gasthuis, Arnhem, The Netherlands
}

(Received 29th August 1968, revised 5th Fanuary 1969)

\begin{abstract}
Summary. Twenty women were treated orally during sixty menstrual cycles with $500 \mu \mathrm{g}$ megestrolacetate daily. Ovulation was not inhibited. In $13 \%$ of the cycles (four of the twenty patients treated) breakthrough bleeding occurred, suggesting that megestrolacetate in the doses employed exerts an influence on the endometrium. Administration of $500 \mu \mathrm{g}$ daily does not have a thermogenic effect. BBT showed a normal biphasic pattern. Ferning and spinnbarkeit of cervical mucus were absent and the mucus became opaque. Post-coital tests became poor or negative. Data are presented suggesting an influence of megestrolacetate on cervical mucus and on the vaginal epithelium.
\end{abstract}

Continuous oral administration of low doses of some progestational agents (Martinez-Manautou, Cortez, Giner, Aznar, Casasola \& Rudel, 1966) seems to produce a local antifertility effect by modification of the endometrium or the cervical mucus without suppression of the hypothalamic-pituitary-ovarian cycle. This paper is not primarily concerned, however, with the contraceptive effects of megestrolacetate (17 $\alpha$-acetoxy-6-methylpregna-4,6-diene-3,20 dione, Novo Industri, Gopenhagen) but with the possible influence of continuous oral administration of megestrolacetate on the ovarian cycle, the endometrium and the cervical mucus.

Megestrolacetate, a progestagen capable of inhibiting ovulation when administered in high doses, has no androgenic, virilizing, anabolic or oestrogenic effects. In this study, twenty women were treated orally during sixty menstrual cycles with $500 \mu \mathrm{g}$ megestrolacetate daily. Administration of such low doses does not appear to inhibit ovulation. Observations were made on menstrual pattern, basal body temperature (BBT), cervical mucus, post-coital tests and the appearance of the vaginal smear.

A group of cooperative patients with extensive data concerning their cycles, BBT and cervical mucus was selected from the sterility ward. They had been married for 3 to 8 years, had tried to become pregnant as long as they were married and none of them had been pregnant before (primary sterility). Routine gynaecological examination revealed no abnormalities. Menstrual cycles were regular with biphasic BBT. Endometrial biopsies during the second half of the cycle showed a normal appearance. Tubal patency was proved by

* Postal address: University Department of Obstetrics and Gynaecology, Nijmegen, The Netherlands. 
insufflation; rhythmic waves at normal pressure were recorded, followed either immediately or hours later by shoulder pain. Hysterosalpingography confirmed the absence of tubal constrictions and dilatations; the corpus and lower uterine segment showed no indications of adhesions or large imperfections. The appearance, viscosity, and presence or absence of spinnbarkeit and ferning of cervical mucus in the first and second half of the menstrual cycle were the same as in normal menstruating women. Sperm counts ranged from 40 to $150 \mathrm{million} / \mathrm{ml}$, with a normal differentiation. Post-coital tests showed a sufficient number of sperm cells of good motility. The excretion of 17-ketosteroids and of 17-hydroxy-corticosteroids was in the normal range. Levels of serum protein-bound iodine were 3 to $8 \mu \mathrm{g} / \mathrm{ml}$. None of the twenty patients

\section{TABLE 1}

THE INFLUENGE ON MENSTRUAL PATTERN OF DAILY ORAL ADMINISTRATION OF $500 \mu \mathrm{G}$ MEGESTROLAGETATE TO 20 PATIENTS DURING 60 cYCLES

\begin{tabular}{l|c|c|c|c}
\hline & \multicolumn{4}{|c}{ Menstrual pattern } \\
\cline { 2 - 5 } & $<21$ days & 21 to 25 days & 25 to 35 days & $>35$ days \\
\hline No. of cycles & 8 & 13 & 39 & 0 \\
$\begin{array}{l}\text { No. of patients } \\
\text { Pattern before megestrolacetate } \\
\quad \text { administration }\end{array}$ & 4 & 3 & 13 & 0 \\
\hline
\end{tabular}

$<21$ days: breakthrough

PATIENTS WITH BREAKTHROUGH BLEEDING

\begin{tabular}{|c|c|c|c|c|}
\hline & Patient 1 & Patient 2 & Patient 3 & Patient 4 \\
\hline $\begin{array}{l}\text { No. of cycles with } \\
\text { breakthrough }\end{array}$ & 1 & 3 & 2 & 2 \\
\hline Comment & $\begin{array}{c}\text { After two } \\
\text { normal cycles }\end{array}$ & $\begin{array}{c}\text { Occ. in three } \\
\text { subsequent cycles }\end{array}$ & $\begin{array}{c}\text { After one } \\
\text { normal cycle }\end{array}$ & $\begin{array}{c}\text { After one } \\
\text { normal cycle }\end{array}$ \\
\hline
\end{tabular}

became pregnant during the period of treatment but after the study was completed two of the patients became pregnant.

The influence of megestrolacetate on the menstrual pattern is given in Table 1 . In $13 \%$ of the cycles (four of the twenty patients treated), breakthrough bleeding occurred. Continuation of the therapy did not result in a normal menstrual pattern. The amount of blood loss during menstruation was reported as normal. The finding of breakthrough bleeding suggests that megestrolacetate, in the doses employed, exerts an influence on the endometrium. Blood loss occurred during the first as well as the second half of the cycle, as shown by the BBT.

Fifteen of the twenty patients recorded their BBT during the administration of megestrolacetate. These records were biphasic in forty cycles and no thermogenic effect was observed. Analysis of the duration of the corpus luteum phase 
was thought to be important as shortening or lengthening of the phase, or change in the moment of rise of BBT could indicate an influence on release of gonadotrophin. None of these changes was observed during therapy.

During the study, thirty-eight random observations were made on the cervical mucus of all the patients. Thirty of the observations appeared to have been made before the BBT had risen. In each of the thirty-eight observations, ferning of cervical mucus was absent, although ferning had been observed in all the patients during the first half of the menstrual cycle before the administration of megestrolacetate. The cervical mucus in each of these observations became opaque and spinnbarkeit was absent, a similar state to that occurring during the second half of the menstrual cycle before the administration of megestrolacetate.

Post-coital tests in twelve patients receiving $500 \mu \mathrm{g}$ megestrolacetate daily were compared with the data observed in the same patients without therapy. Test gradings were based on the average number of sperm cells showing progressive movement per single high-power field $(\times 400)$ (ten HP fields at least examined): (1) negative, no cells; (2) poor, up to five cells of slow to moderate motility; (3) regular, up to five cells of fairly good to very good motility; (4) good, more than five cells of grade (3) motility; (5) excellent, more than twenty cells of grade (3) motility. Before therapy, post-coital test gradings were regular in two patients, good in eight patients and excellent in two patients. During treatment with megestrolacetate, tests were negative in four patients and poor in the remaining eight patients. Cervical mucus from four patients under therapy was placed on a glass slide under a cover-slip near a drop of fresh donor semen. After $2 \mathrm{hr}$, the few sperm cells that had penetrated into the mucus were markedly immobilized, whereas the cells that had not penetrated showed good motility.

Cervical mucus from five patients under treatment was pooled, dried under nitrogen at $30^{\circ} \mathrm{C}$, dissolved in ethanol and subjected to thin layer chromatography on silica gel using benzene:ethanol $(8: 2)$ as the liquid phase. The region corresponding to reference megestrolacetate was scraped off, eluted with peroxide-free ether, dried, dissolved in ethanol and measured spectrophotometrically in a Beckmann DU-2 spectrophotometer. Megestrolacetate has an absorption maximum at $288 \mathrm{~m} \mu$, but extracts of the mucus did not show any absorption at this level. It could be calculated that less than $5 \mu \mathrm{g}$ megestrolacetate had been present in the mucus of the five patients, i.e. less than $1 \mu \mathrm{g}$ per patient, indicating that the influence of megestrolacetate on cervical mucus may be an indirect one.

Twenty-five vaginal smears were taken for cytological examination during the administration of megestrolacetate, fifteen during the first half of the cycle as judged by BBT. In all twenty-five smears, a progesterone-like picture was found. These findings indicate that megestrolacetate, in the doses employed, has an influence on the vaginal epithelium as well as on the cervical mucus.

\section{REFERENCE}

Martinez-Manautou, J., Cortez, V., Giner, J., Aznar, R., Casasola, J. \& Rudel, H. W. (1966) Low doses of progestogen as an approach to fertility control. Fert. Steril. 17, 49. 